\title{
Bank Fraud and Financial Intermediation: A Supply-side Causality Analysis
}

\author{
By Daibi W. Dagogo ${ }^{\dagger}$ \\ Tamunonimim A. Ngerebo- $a^{*}$
}

\begin{abstract}
This paper investigates supply-side fraud elasticities of financial intermediation. Three rationales that make intermediation inevitable in modern economics were identified as dependent variables: reduction of transaction cost, transformation of risk, and transformation of liquidity. They were represented by operating cost, valueat-risk, and liquidity ratio, respectively. The independent variables stated in monetary value are unauthorized loans, theft \& robbery, and fraudulent withdrawal. These variables were preferred after detailed literature review in the area. Three OLS-type multiple regression models were formulated to estimate the values of the dependent variables and the coefficients of the independent variables. Stationarity test, co-integration test, and Granger causality test were conducted for purposes of ensuring reliability of the time series data collected from NDIC, CBN and NBS in respect of the variables listed above. F-test and t-test were conducted to ascertain the statistical significance of the results. The coefficients of the independent variables were then used to evaluate the dependent variables on account of their responsiveness to changes in bank fraud. It was found that financial intermediation is inelastic to bank fraud. It was concluded that as a result of the minute elasticity, financial intermediation cannot be threatened by fraud but incidence of fraud is a signal for intermediaries and regulators to be alive to the responsibilities.
\end{abstract}

Keywords: Bank fraud, financial intermediation, asymmetric information, transaction cost.

\section{Introduction}

Rising incidences of fraud in Nigerian banks, occasioned by the growing proportion of banked population, deepening financial inclusion, and widening acceptance of virtual banking have caused increased concern about confidence, safety, security and related issues within the financial sector. This concern is further heightened by the increasing role of banks as financial intermediaries responsible for creating money in the economic system. Such concerns are recipes for financial reforms that match existing technology and the growing complexities of the instruments of fraud.

The financial world has never been the same since the idea that investors or debt holders do not have to deal directly with investees or debtors was mooted, just as the smart ideas of the $18^{\text {th }}$ century Goldsmiths of London brought about

\footnotetext{
${ }^{\dagger}$ Senior Lecturer, Department of Banking and Finance, Rivers State University, Port Harcourt, Nigeria.

${ }^{*}$ Reader, Department of Banking and Finance, Rivers State University. Port Harcourt, Nigeria.
} 
fiat money, fractional reserve banking, and bank's ability to create money (Afolabi 2005).Underlying these financial developments are trust, confidence, soundness, prudence, perpetuity, liquidity, stability and the likes. Crisis occurs when these attributes are compromised. Financial regulations such as the prudential guidelines and Basel one, two and three were introduced to ensure that these attributes are not compromised, as the consequences of their retraction could be catastrophic. Again, various reforms in the Nigerian banking sector such as the deregulation of the sector in 1986, the adoption of universal banking scheme in 2001, and the banking sector consolidation of 2006 were undertaken to assert confidence in the banking system. (Toby 2008)

Following the collapse of several banks in the early years of banking in Nigeria, banks inevitably adhered to fraud prevention standards in order to avoid distress. (Igweike 2008). In other words, bank fraud has the capacity of weakening intermediation functions if trust, confidence, soundness, prudence, etc. are retracted. This paper estimates the extent to which bank fraud can contribute to bank distress through their effect on banks' ability to perform intermediation roles such as reduction of transaction cost, transformation of risk, and provision of liquidity. The relevant question is: to what extent do unauthorized loan, theft and robbery, and fraudulent withdrawals affect banks' transaction cost, risk transformation, and provision of liquidity?

\section{Review}

When households with resources to invest purchase securities issued directly by firms, there is no intermediation. That is, the deficit sector could actually borrow or deal directly with investors in the capital markets if they know where the market is and assume greater uncertainties than otherwise acceptable. Direct transactions have been shown in several theories to be less efficient and more expensive to both investor and investee. Theories of intermediation include transaction cost, transformation of maturity period with its attendant default risk, transformation of claims, delegated monitoring, asymmetric information, and transformation of liquidity. (Gorton and Winton 2003, Greenbaum and Thakor 2007a, Cecchetti and Schoenholtz 2015). It should be noted that whilst there are other financial intermediaries such as private equity and mortgage institutions, it is the pervasiveness of bank-financial intermediaries that inspires greater attention to that sector, enabling it appear as the generic class for intermediation. (Sahlman 1990, Greenbaum and Thakor 2007b)

\section{Reduction of Transaction Cost}

Although the development of modern banking owes its history to many related accounts, especially, the contributions of the goldsmiths of London, the merchants of Venice, the drapers of Barcelona, and the mariners of Amsterdam, reduction of cost associated with indirect financing was not advanced as an ex 
ante reason for the emergence of bank, (Shekhar and Shekhar 2007). This changed when Diamond (1984) asserted that since monitoring borrowers in direct financing is costly, it is efficient to delegate the task to a specialized agent, the bank. Earlier, Townsend (1979) had demonstrated that the act of monitoring borrowers is not only costly but it is also contingent on the amount of the payment. Ever then, this notion has received considerable attention, pervading the entire spectrum of transaction cost economics.

Gorton and Winton (2003) gave account of the implication of transactions costs on the payment system, stating that centralizing this process at the level of financial intermediaries avoids wasteful duplication of verification costs. Dewatripont and Tirole (1994) noted that earlier vision of bank as instrument of transaction cost reduction was incomplete if one considers monitoring costs alone without including others like audit costs. Also, Scholtens and Wensveen (2003) argued for an amendment of the contemporary theory of intermediation in the light of incremental knowledge and suggested that transaction cost advantage of intermediaries could be replaced with value creation advantage. Diamond (1984) also advanced the implicit transaction cost associated with bankruptcy or loss of reputation, an argument that was further tested by Williamson (1986), Winton (1995), and Wariboko (1998).

\section{Reduction of Risk}

One of the key rationales for intermediation is the transformation of quality asset. The attributes of assets likely to be transformed are: duration, divisibility, liquidity, credit risk and currency identity. Greenbaum and Thakor (2007c) explained that intermediary will shorten the duration of the claims of its clients by holding assets of longer duration than its own liabilities; it will reduce the unit size of the claims of its clients by holding assets of larger units size than its liabilities; it will enhance the liquidity of the claims of its clients by holding assets that are more illiquid than its liabilities and it will reduce credit risk by holding assets that are more likely to default than its liabilities. Each of these attributes, entails a mismatch of the attributes as explained above on the intermediary's balance sheet. These mismatches produce variations which introduce different types of risk, such as interest rate risk, foreign exchange risks, inventory risk, liquidity risk, and default risk. Scholtens and Wensveen (2003) argued that the essence of intermediation is risk management rather than reduction of the problem of information asymmetry or transaction costs, stating that economies of scale and delegation of the screening function apply to dealing with risk rather than with information. Financial intermediaries are able to assume inevitable risks because they create comparative advantages with respect to information acquisition, processing, and reusability in relation to their size.

\section{Provision of Liquidity}

In the view of Gorton and Winton (2003), the observation that bank liabilities function as a medium of exchange leads to different liquidity models that are quite 
distinct and perhaps more natural than viewing bank liabilities as allowing consumption smoothing. This generates a need for a payment system, essentially a trading center that can produce and sell claims. A second notion of liquidity is related to the information properties of claims that are privately produced as a medium of exchange. The focus is on reducing trading losses that agents who need to consume face when other traders with private information seek to use this information to make trading profits. Yet a third notion of liquidity uses a setting where moral hazard problems limit firms' ability to borrow to meet unexpected investment needs. Because moral hazard limits the effectiveness of transactions between firms with excess liquidity and firms that need liquidity, a bank that provides contingent liquidity to those that need it can dominate a decentralized market. The first view of banks as liquidity providers concerns the role of banks in the payments system. Banks face constant liquidity trade-offs; to invest in short-term (liquid) assets and not to perform their term-transformation function or to invest (at least partially) in long-term assets and face the possibility of bank runs. (Mishkin and Eakins 2004). A landing pad for this problem is to insure deposits that guarantee the depositors, at least, a proportion of their money. This prevents bank runs and suggests an allocation of resources, which is superior to the one without insurance. At the same time, the need of deposit insurance illustrates the necessity of regulatory intervention.

\section{Concept of Fraud}

The criminal instinct in man combines with deviant tendencies and pursuit of self-interest to explain the natural curiosity of men to perpetuate bank fraud. Unfortunately, it is destructive rather than constructive self-interest of Adam Smith's philosophy of capitalism that provides the incentive for fraud. It is imagined that cases of bank fraud would be as old as the existence of banks, more so, where an estimated forty percent of all incidences of bank fraud are traced to management or staff. Other factors include inadequate manpower, poor internal control system, negligence, poor corporate governance structure, condition of workers, societal value, economic challenges, and porous legal system (Akindele 2005, Alleyne and Howard 2005, Adeyemo 2012, Adewale 2011).

Fraud is any illegal act characterized by deceit, concealment or violation of trust, which may not depend on the application of threat of violence or physical force. Fraud is an antithesis of trust, good faith, fidelity, and fiduciary (Palmay and Di Lorenzo 2010). Awe (2005) defines fraud as the intentional alteration of records accompanied by the defalcation of asset in order to deceive certain group of people for the benefit of the perpetrator. It covers a range of irregularities and illegal acts characterized by intentional deception, perpetrated for the benefit of or to the detriment of the organization and by an insider or outsider. It is also described as means of getting advantage over another by suppressing the truth, misinformation, false suggestions, cunning, deceit, etc. By extension, bank fraud includes embezzlement, theft, robbery, or any attempt 
to unlawfully obtain the assets of banks. There is a common agreement amongst criminologists that fraud takes place if perpetuators have the will to commit fraud, there is an inherent opportunity, and an exit to escape from sanctions or punishments if caught. (Idolor 2010). Recent literature differentiates between first party and third party fraud. In first party fraud, a legitimate customer betrays the bank, whereas in the third party fraud, the customer becomes a victim of the fraudsters who steal identities, use lost or stolen cards, counterfeit cards or gain unauthorized access to customers account by physical means or via virtual platforms (Owolabi 2010, Gates and Jacob 2009, Greene 2009).

In Nigeria, sections 35 and 36 of Nigerian Deposit Insurance Corporation (NDIC) Act 2006 mandates banks to render monthly returns of frauds and forgeries, and also notify the corporation of any staff dismissed or whose appointment was terminated on accounts of frauds or financial irregularities. Within eight years, a total of 3,337 staff were reported to have been involved in frauds and forgeries, while between 2011 and 2012 a total of 1,029 staff were reported to have taken part in financial impropriety. These statistics accounted for 30.83 percent of the whole figure. Undoubtedly, fraud leads to loss of money which belongs to either the bank or customers. This loss results in a decline of productive resources available to the bank. Adewunmi (1986) identified the following effects of bank frauds: destruction of bank's reputation, loss of confidence among banking public, reduction of staff welfare, distrust among staff, competitive disadvantage, and low bottom line. On the aggregate, bank fraud is on the increase, as it rose from 1,461 in 2014 to 10,743 in 2015.

More worrisome is the positive relationship between the adoption of electronic banking and the incidence of fraud. Forty-three percent of bank frauds in Nigeria takes place in automated teller machines. (NIBSS 2016). This is instructive, and the regulatory authorities have stepped in with controls such as the introduction of biometric verification number $(\mathrm{BVN})$, treasury single account (TSA), dematerialization of dividend certificate, and electronic dividend payment project.

The causes of fraud are grouped into two classes: institutional and socioenvironmental factors. Institutional factors are traceable to the internal environment of the bank while socio-environmental factors are those which result from the influence of the society and environment on the banking industry (Ojo 2008). There are three broad categories of bank fraud perpetrators: internal, external and mixed. Internal perpetrators of frauds are members of staff while external perpetrators are persons not connected with the bank. Mixed perpetrators involve outsiders colluding with bank staff. The most common types of bank fraud include advance fee fraud, account opening fraud, cheque fraud, computer fraud, clearing fraud, letters of credit fraud, money transfer fraud, loan fraud, wire transfer fraud, bill discounting fraud, internet banking fraud, ATM fraud, theft and embezzlement, defalcation, fraudulent substitution, payment against unclear effects, unauthorized lending, lending to ghost borrowers, over/under valuation of properties, fraudulent use of bank documents, falsification of status report, duplication of cheque books, interception of clearing cheques, laundering, 
robberies, fake payment, and claim of supernatural influence. (Owolabi 2010, Tolu and Ogunro 2012)

There are three known theories of fraud: First is differential opportunity theory, which states that people have the opportunity to commit fraud against their employers, suppliers, customers, third parties, and government departments. Such opportunity is informed by access to accounts, assets, premises and computer systems, skill required to identify and utilize opportunity, and available time to plan and execute the fraud. Second is concealment theory, which involves the manipulation of accounting record or misrepresentation of a physical, personal or commercial reality intended to hide, disguise or alter an account or inventory before, during or after a fraudulent act. The theory explains the introduction of confusion during or after the act in order to conceal the act. Third, fraud is deviant behavior and perpetrators often conceal their dishonesty as plausible breaches of rules or procedures. It is a deviation from a normal procedure. More often, the perpetrators are limited to the available opportunities and also concentrate on ways to conceal their guilt (Comer 1986).

\section{Research Methods}

Secondary data were extracted from various publications of Nigerian Deposit Insurance Corporation, Central Bank of Nigeria statistical bulletin, banks annual reports, Nigeria Inter-Bank Settlement System (NIBSS), and Nigeria Electronic Fraud Forum (NEFF). Three models were developed: the first model has transaction cost as dependent variable, and the proxy is total operating cost of banks. In this sense, financial intermediaries perform brokerage functions by bringing together two parties in complementary financial needs. To fit properly and assuage the problem of both pre- and post-contract information asymmetry, banks have to build moat through economies of scale and develop expertise in information technology and skills in order to reduce their transaction costs through reusability of information. We considered that operating cost reflects bank's ability to gain both economies of scale and expertise. In other words, the higher the total operating cost, the greater is the scope of operation, and the lower will be the operating cost per unit of transaction. Here, we seek to understand the extent to which bank fraud deepens operating cost.

The second model has value-at-risk as the dependent variable, representing transformation of risk. Risks arise from mismatches between assets and liabilities in the bank's balance sheet. Almost every quality asset transformed also exposes the bank to some risk as long as there is a mismatch of these attributes on the intermediary's balance sheet (Greenbaum and Thakor 2007d). For example, a mismatch between the maturities of a bank's liabilities (i.e. demand deposits) against those of its assets (loans to deficit sectors) cause interest rate risk, default risk and liquidity risk. Therefore, value-at-risk will be the amount of performing and non-performing loan assets that are likely to cause these risks.

The third is borne from bank's ability to provide liquidity. This is done in two ways: first by swapping demand deposits for illiquid loan assets, thus, 
modifying the claims held by its clientele, and being rewarded with the interest rate spread between deposits and loans. The second way is through bank's ability to create money (Greenbaum and Thakor 2007e). That is, by issuing cheques worth more than the amount of deposits in its vault, banks provide liquidity within the financial system for the benefit of the deficit unit. Accordingly, we have two proxies to choose from: a measure of the bank's ability to provide liquidity in place of illiquid assets, and a measure of banks capacity to create money. The former is represented by the ratio of total withdrawal to total credit, and it appeals more to us here.

\section{Model Specification and Estimation Procedure}

The model specification took account of the effect of three dimensions of bank fraud on three supply-side justifications for financial intermediation: granting of unauthorized loans, theft \&robbery, and fraudulent withdrawals. For the purpose of this study, withdrawals included over-the-counter cash withdrawals, electronic transfers, and presentation of forged instruments or mandates for withdrawal such as forged cheques. Other forms of bank fraud that are not the immediate focus of this study in addition to non-bank fraud effects on the dependent variables are part of the disturbance term usually explained away in economic analysis as other things being the same.

The concept of financial intermediation is bi-dimensional: supply-side and demand-side effects. The former hinges on the duty of a bank to receive deposits from customers or surplus units, and the latter rests on the bank's duty to make loans to the deficit units. This study examines the effect on the supply-side. Time series data for fifteen years running from 2001 to 2015 were collected. Three multiple regression models were formulated representing each of the three dependent variables, using ordinary least square (OLS) estimation procedure. This was based on the following assumptions: linearity of the regression model; $\chi$ variables are independent of the error term, i.e. $\operatorname{cov}\left(u_{i}, X_{2 i}\right)=\operatorname{cov}\left(u_{i}, X_{3 i}\right)=0$; there is zero mean value of the disturbance term $u_{i}$; constant variance of the disturbance term $u_{i}$, i.e. $\operatorname{var}\left(u_{i}=\delta^{2}\right)$; no autocorrelation or serial correlation between the disturbances such that $\operatorname{cov}\left(u_{i}, u_{j}\right)=0, i \neq j$; and $n>3$. (Gujarati, Porter, \& Gunasekar 2013). The functional relationships between the variables are of the following forms: $T C=f(U L, T \& R, F W) ; T R=f(U L, T \& R, F W) ; T L=f(U L, T \& R, F W)$

Where $T C$ equals transaction cost; $f$ is the functional notation; $U L$ equals unauthorized loans; $T \& R$ equals theft and robbery; $F W$ equals fraudulent withdrawals.TR equals transformation of risks; and $T L$ equals transformation of liquidity. Operationalizing these variables for OLS estimation takes the following form:

$$
\begin{gathered}
O C_{t}=a+\beta_{1} U L_{1 t}+\beta_{2} T \& R_{2 t}+\beta_{3} F W_{3 t}+u_{t} \ldots \ldots \ldots \ldots \ldots \text { eq } 1 \\
V @ R_{t}=a+\beta_{1} U L_{1 t}+\beta_{2} T \& R_{2 t}+\beta_{3} F W_{3 t}+u_{t} \ldots \ldots \ldots \ldots \ldots \ldots e q 2 \\
L R_{t}=a+\beta_{1} U L_{1 t}+\beta_{2} T \& R_{2 t}+\beta_{3} F W_{3 t}+u_{t} \ldots \ldots \ldots \ldots \ldots \ldots e q 3
\end{gathered}
$$


Where $a$ equals the intercept of the $Y$ (dependent variable) axis; $\beta s$ are the partial regression coefficients; subscript $t$ denotes $t$ th time observations; $O C$ equals operating cost; $V @ R$ equals value at risk; and $L R$ equals liquidity ratio. The independent variables are as defined above. The sample regression functions (SRF) corresponding with the partial regression coefficients are written thus:

$$
\begin{aligned}
& \text { ôc } \hat{\mathrm{C}}_{t}=\mathrm{a}+\beta_{1}{ }^{\mathrm{n}} U L_{1 t}+\beta_{2}{ }^{\mathrm{n}} T \& R_{2 t}+\beta_{3}{ }^{{ }^{n}} F W_{3 t}+\hat{\mathrm{u}}_{t} \ldots \ldots \ldots \ldots \ldots \text { eq } 4 \\
& V @ \hat{\mathrm{R}}_{t}=\hat{\mathrm{a}}+\beta_{1}{ }^{\mathrm{n}} U L_{1 t}+\beta_{2}{ }^{n} T \& R_{2 t}+\beta_{3}{ }^{\mathrm{n}} F W_{3 t}+\hat{\mathrm{u}}_{t} \ldots \ldots \ldots \ldots \ldots \text {.... } 5 \\
& L R_{t}=\hat{\mathrm{a}}+\beta_{1}{ }^{\mathrm{n}} U L_{1 t}+\beta_{2}{ }^{n} T \& R_{2 t}+\beta_{3}{ }^{n} F W_{3 t}+\hat{\mathrm{u}}_{t} \ldots \ldots \ldots \ldots \ldots \text { eq } 6
\end{aligned}
$$

The estimation procedure involves choosing the values of the unknown parameters so that the residual sum of squares (RSS) $\sum \hat{\mathrm{u}}_{i}^{2}$ is as small as possible. (Gujarati, Porter, and Gunasekar, 2013).Such is symbolically presented for equation 4, and as applicable for equations 5 and 6 on account of the changing the dependent variables.

$$
\begin{aligned}
\min \sum \hat{\mathrm{u}}_{i}{ }^{2}= & \sum\left(\hat{\mathrm{O}} \hat{\mathrm{C}}_{t}-\hat{\mathrm{a}}-\beta_{1}{ }^{ } U L_{1 t}-\beta_{2}{ }^{n} T \& R_{2 t}\right. \\
& \left.-\beta_{3}{ }^{\mathrm{n}} F W_{3 t}\right)^{2} \ldots \ldots \ldots \ldots \text { eq } 7
\end{aligned}
$$

To increase the reliability of the data, test of stationarity was conducted to assure us that data were stationary at difference; co-integration test was also conducted to ascertain the presence or otherwise of long run effect of the independent variables on the dependent variables; and Granger causality test validated the significance of the causality between the dependent and independent variables. (See table 2 under appendix)

\section{Results and Discussion}

From the result presented in table 1 (see appendix), the overall goodness of fit of equation 4 is plausible. 66 percent of the variation in operating cost is explained by the independent variables. The observed value of F-test is significant at 4.7 percent. The Durbin-Watson value (DW) of 1.59 meets the strict requirement, indicative of the absence of serial autocorrelation. The p-values of two independent variables, $\mathrm{T} \& \mathrm{R}$ and $\mathrm{FW}$, are statistically significant at $p=0.05$, indicating that both variables contribute significantly to changes in operating cost. In equation 5, about 71.9 percent of the variation in value-at-risk is caused by the independent variables. The value of F-test, 4.1069, is statistically significant with a p-value of 0.0391 . The Durbin Watson value of 1.58 satisfies the maximum criterion of 1.7; and the explanatory variables proved that only T\&R and FW contributed significantly to changes in value-at-risk. Equation 6 conveys similar trend, indicating that $\mathrm{T} \& \mathrm{R}$ and $\mathrm{FW}$ recorded statistically significant contributions to changes in liquidity ratio.

From table 1 (see appendix), the models revealed that there is long run relationship between the dependent and the independent variables. The models 
proved at least two co-integrating equation, thus rejecting any counter hypotheses. The test statistics and results of the Granger causality tests are found in the appendix. To interpret the results, we have the following benchmarks: Where $\varepsilon_{B F}$ equals bank fraud elasticity of financial intermediation, if $\varepsilon_{B F}=0$, there is perfect inelasticity; if $\varepsilon_{B F}=1$, there is unitary elasticity; if $\varepsilon_{B F}=\infty$, there is perfect elasticity; if $0<\varepsilon_{B F}<1$, then there is inelasticity; and if $0<\varepsilon_{B F}<\infty$,then there is elasticity. (Koutsoyiannis 2006). In equation 4, a one percent change in UL, TR, and FW caused OC to change by 0.05 percent, 0.79 percent, and 0.63 percent respectively. In each case, the elasticities are less than unitary and are not perfect. Besides, the result for UL ( 0.05 percent) failed test of statistical significance. The sign $0<\varepsilon_{B F}<1$ indicates that the OC is inelastic to changes in UL, TR, and FW. In equation 5, a one percent change in UL, TR, and FW caused TR to change by 0.45 percent, 0.64 percent and 0.45 percent respectively. Again, the elasticities are less than unitary, are not perfect, and only those for TR and FW are statistically significant. The trend is the same with equation 6 where the bank fraud elasticities are 0.03 percent, 0.9 percent, and 0.52 percent for UL, TR, and FW respectively. The prevalent sign is $0<\varepsilon_{B F}<1$ indicating that the TL is inelastic to changes in UL, TR, and FW.

It appears simple and obvious to articulate a position without hesitation that incidences of bank fraud have inverse and repressible effect on bank deposits and therefore on the rationale for bank intermediary in terms of transaction cost reduction, spreading of risk, and provision of liquidity. What has remained opaque has been the degree of elasticity associated with this inverse relationship. Covertly put, how much of confidence in the banking industry get eroded for every incidence of bank fraud? This question is only relevant if we admitted ab initio that trust and confidence are building blocks of the intermediation process, and that if these attributes are impaired, they affect the supply-side of the same process. In that sense, the corporate judgements or inferences were more decisive as shown by the results of the F-tests. The individual inferences leave much to be desired in terms of their elasticities, as they all bear features of inelasticity. Now we know that irrespective of the perfidiousness, distrust and infidelity associated with fraud, we cannot discontinue financial intermediation processes, as measured by the responsiveness of financial intermediation to an incidence of fraud. Contrary views are held by other scholars, views that in our opinion are divested of specificity of details. One of such is the conclusion of Okoye and Gbegi (2013) on the effect of corruption on the growth and development of Nigerian economy. Evidence over the years has shown that fraud results in banks failure and liquidation that impact negatively on deposit mobilization and credit allocation in the economy. Indeed, an obvious fact or self-evident truth that was merely restated. This work, moved away from such blanket-like statements to evidence-based specificities. 


\section{Conclusion}

It is important to note that fraud affects the operational efficiency of any banking institution, limits profitability, erodes the confidence placed in the banking system, and diminishes the soundness of the financial system. It is the same reason the financial sector happens to be the most regulated sector of the economy. In other words, faithlessness and infidelity are some of the reasons for stern regulation. This in turn justifies the rising interest in investigating intermediation problems like transaction cost, asymmetric information and agency cost. That said, we note here that the overall effect of bank fraud on financial intermediation as expressed in their elasticities is not such that will threaten the existence of intermediaries but would only keep them alive to their responsibilities of abating distress, particularly in this era of value creation through innovative service delivery. This work is also completed not without shortcomings. We have not ruled out the possibility of omitting certain instrumental variables that are critical to this study. Such may serve as basis for further studies in this area.

\section{References}

Adewale SB (2011) The crowding-out effects of corruption in Nigeria: An empirical study. Journal of Business Management and Economics 2(2): 59-68.

Adewumi W (1986) Fraud in Banks: An Overview. Lagos: Landmark publication ltd.

Adeyemo KA (2012) Frauds in Nigerian banks: nature, deep-seated causes, aftermaths, and probable remedies. Mediterranean Journal of Social Sciences 3(2): 279-289

Afolabi L (2005) Law and Practice of Banking. Ibadan: Heinemann educational books (Nigeria) PLC.

Akindele ST (2005) A critical analysis of corruption and its problems in Nigeria. Anthropologist 7(1): 7-18

Alleyne P, Howard M (2005) An exploratory study of auditors' responsibility for fraud detection. Managerial Auditing Journal 20(3): 284-303.

Awe OI (2005) The Theory and Practice of Auditing. Akure: Adeyemo publishing house.

Cecchetti S, Schoenholtz K (2015) Money, Banking and Financial Markets. New York: McGraw Hill Education

Central Bank of Nigeria (2015) Full annual report. Retrieved from https://www.cbn. gov.ng/documents/annualreports.asp

Comer MJ (1985) Corporate Fraud. London: McGraw-Hill Book Company (UK) Limited.

Diamond D (1984) Financial intermediation and delegated monitoring. Review of Economic Studies 8: 393-414

Diamond D (1991) Monitoring and reputation: The choice between bank loans and directly placed debt. Journal of Political Economy 99(6): 689-721.

Dewatripont M, Tirole J (1994) A theory of debt and equity: diversity of securities and manager-shareholder congruence. Quarterly Journal of Economics 109: 1027-1054.

Gates T, Jacob K (2009) Payments fraud: perception versus reality. Economic Perspectives 33(1): 7-15. 
Gorton G, Winton A (2003) Financial intermediation. In Constantinides GM, Harris M and Stulz RM (eds) Handbook of the Economics of Finance: Financial Markets and Asset Pricing. Amsterdam: Elsevier, 431-552.

Greenbaum S, Thakor A (2007a,b,c,d,\&e) Contemporary Financial Intermediation. London: Elsevier.

Greene MN (2009) Divided we fall: fighting payments fraud together. Economic Perspectives 33(1): 37-42.

Gujarati D, Porter D and Gunasekar S (2013) Basic Econometrics. New Delhi: Tata McGraw Hill education Private Ltd.

Idolor E (2010) Bank frauds in Nigeria: Underlying causes, effects and possible remedies. African Journal of Accounting, Economics, Finance and Banking Research. 6(6): 6280

Igweike KI (2008) Law of Banking and Negotiable Instruments. Lagos: Africana first Publishers ltd.

Koutsoyiannis A (2006) Modern Microeconomics. Basingstoke: McMillan press ltd.

Mishkin F, Eakins S (2004) Financial Markets and Institutions. Boston: Prentice Hall Publishers.

Ojo JA (2008) Effect of bank frauds on banking operations in Nigeria. International Journal of Investment and Finance 1(1): 9-14.

Okoye FI, Gbegi DO (2013) An evaluation of the effect of fraud and related financial crimes on the Nigerian economy. Kuwait Chapter of Arabian Journal of Business and Management Review 2(7): 81-90.

Owolabi SA (2010) Fraud and fraudulent practices in Nigeria banking industry. African Research Review 4(3b): 240-256.

Palmay F, Dilorenzo A (2008) Fraud and misconduct by financial intermediaries. Retrieved from www.mcmillan.co/files/142508.

Sahlman W (1990) The structure and governance of venture capital organizations. Journal of Financial Economics 27(9): 473-521.

Shekhar K, Shekhar L (2007) Banking Theory and Practice. New Delhi: Vikas publishing house.

Scholtens B, Wensveen D (2003) The theory of financial intermediation: an essay on what it does (not) explain. SUERF Studies: The European Money and Finance forum. Vienna.

Toby AJ (2008) Monetary policy, capital adequacy regulation and banking system soundness in Nigeria: Empirical research findings. Journal of Financial Management and Analysis 21(1): 32-46.

Tolu L, Ogunro K V (2012) Combating corruption in Nigeria. International Journal of Academic Research in Economics and Management Sciences 1(4): 2226- 3624.

Townsend R (1979) Optimal contracts and competitive markets with costly state verification. Journal of Economic Theory 21(2): 265-293.

Wariboko N (1998) A theory of the canoe house corporation. African Economic History 26: $141-172$.

Williamson S (1986) Costly monitoring, financial intermediation, and equilibrium credit rationing. Journal of Monetary Economics 2(18): 159-179.

Winton A (1995) Delegated monitoring and bank structure in a finite economy. Journal of Financial Intermediation 4(2): 158-187.

Winton A (2001) Institutional liquidity needs and the structure of monitored finance. Working Paper, University of Minnesota. 


\section{Appendix}

Table 1. Summary Statistics of Analyses

\begin{tabular}{|l|c|c|c|c|c|c|}
\hline Model & $\mathbf{R}^{2}$ & $\begin{array}{c}\text { F- } \\
\text { Value }\end{array}$ & Parameters & Coefficients & $\begin{array}{c}\text { t- } \\
\text { tests }\end{array}$ & $\begin{array}{c}\text { p- } \\
\text { values }\end{array}$ \\
\hline$T C=f(U L, T \& R, F W)$ & 0.6637 & 3.5520 & UL & 0.0005 & 0.246 & 0.8109 \\
\hline Dep. Variable: OC & & $\begin{array}{c}\text { F- } \\
\text { Prob. }\end{array}$ & T\&R & 0.0079 & 3.810 & 0.0501 \\
\hline & & 0.0474 & FW & 0.0063 & 3.501 & 0.0067 \\
\hline$T R=f(U L, T \& R, F W)$ & 0.7196 & 4.1069 & UL & 0.00054 & 0.364 & 0.7251 \\
\hline Dep. Variable: V@R & & $\begin{array}{c}\text { F- } \\
\text { Prob. }\end{array}$ & T\&R & 0.00688 & 4.825 & 0.0055 \\
\hline & & 0.0391 & FW & 0.00450 & 3.919 & 0.0044 \\
\hline$T L=f(U L, T \& R, F W)$ & 0.6036 & 4.1520 & UL & 0.0003 & 0.246 & 0.7102 \\
\hline Dep. Variable: & & $\begin{array}{c}\text { F- } \\
\text { Prob. }\end{array}$ & T\&R & 0.0094 & 6.610 & 0.0251 \\
\hline & & .03446 & FW & 0.0052 & 2.571 & 0.0015 \\
\hline & & & $a$ & 4.1416 & 1.913 & 0.0355 \\
\hline
\end{tabular}

Note: DW remains at $1.59,1.92$, and 2.08 for the first, second and third models respectively. Source: Extracted from E-view 9.0

Table 2. Data Set for Dependent and Independent Variables

\begin{tabular}{|c|c|c|c|c|c|c|}
\hline Year & $\begin{array}{c}\text { Transaction } \\
\text { cost (b\#) }\end{array}$ & $\begin{array}{c}\text { Value- } \\
\text { @ - } \\
\text { risk } \\
(\mathrm{b} \#)\end{array}$ & $\begin{array}{l}\text { Liquidity } \\
\text { ratio }\end{array}$ & $\begin{array}{c}\text { Unauthorized } \\
\text { loan (b\#) }\end{array}$ & $\begin{array}{c}\text { Fraudulent } \\
\text { withdrawals(b®) }\end{array}$ & $\begin{array}{l}\text { Theft } \\
\text { and } \\
\text { robbery } \\
(b \AA)\end{array}$ \\
\hline 2001 & 27,345 & 552 & 0.84 & 10.56 & 270.65 & 24.41 \\
\hline 2002 & 32,340 & 784 & 1.02 & 13.14 & 310.50 & 35.64 \\
\hline 2003 & 43,459 & 702 & 1.23 & 19.45 & 347.17 & 43.55 \\
\hline 2004 & 59,034 & 954 & 1.81 & 59.15 & 560.45 & 45.56 \\
\hline 2005 & 103,243 & 936 & 2.47 & $1,413.75$ & 759.10 & 160.15 \\
\hline 2006 & 150,324 & 1,310 & 3.41 & 157.92 & 551.00 & 105.33 \\
\hline 2007 & 231,144 & 1,415 & 5.36 & 369.38 & $3,012.29$ & 233.11 \\
\hline 2008 & 342,985 & 2,331 & 8.70 & $5,847.70$ & $3,121.50$ & $1,100.00$ \\
\hline 2009 & $1,320,944$ & 5,010 & 9.99 & $15,164.10$ & $5,200.00$ & $6,192.00$ \\
\hline 2010 & 754,324 & 2,701 & 10.84 & $2,000.00$ & $1,010.00$ & $1,037.00$ \\
\hline 2011 & 876,656 & 3,119 & 12.33 & 900.00 & 902.00 & 927.00 \\
\hline 2012 & 868,365 & 3,897 & 14.39 & 430.00 & $1,162.00$ & 295.00 \\
\hline 2013 & 754,354 & 4,517 & 16.77 & 511.00 & $1,160.00$ & 370.00 \\
\hline 2014 & 879,655 & 7,843 & 17.00 & 605.00 & $2,019.00$ & 492.00 \\
\hline 2015 & 765,787 & 8,236 & 17.20 & 772.00 & $1,512.00$ & 410.00 \\
\hline
\end{tabular}


Test For Stationarity: Level Series

\begin{tabular}{|c|c|c|c|c|c|c|}
\hline \multirow{2}{*}{ Variables } & \multirow{2}{*}{ Adf } & \multicolumn{3}{|c|}{ CriticalValue } & \multirow{2}{*}{ Prob } & \multirow{2}{*}{ Order of int. } \\
\cline { 3 - 5 } & & $1 \%$ & $5 \%$ & $10 \%$ & & \\
\hline OC & -2.430024 & -4.582648 & -3.320969 & -2801384 & 0.1627 & $1(0)$ \\
\hline V@R & -2.112422 & -2.771926 & -1.974028 & -1.602922 & 0.9857 & $1(0)$ \\
\hline TL & -2.132133 & -2.657654 & -1.632322 & -1.685426 & 0.3212 & $1(0)$ \\
\hline UL & -2.276373 & -2.728252 & -1.966270 & -1.605026 & 0.0264 & $1(0)$ \\
\hline T\&R & -1.902147 & -2.728252 & -2.728252 & -2.728252 & 0.0568 & $1(0)$ \\
\hline FW & -4.882401 & -2.740613 & -1.968430 & 1.604392 & .0001 & $1(0)$ \\
\hline
\end{tabular}

Stationarity at Difference

\begin{tabular}{|c|c|c|c|c|c|c|}
\hline OC & -3.051660 & -2.886101 & -1.995865 & -1599088 & 0.0074 & $1(0)$ \\
\hline V@R & -7.015243 & -3.109582 & -2.043968 & -1.597318 & 0.0002 & $1(0)$ \\
\hline TL & -5.768543 & -3.098649 & -3.435823 & -1.728252 & 0.0002 & $1(0)$ \\
\hline $\mathbf{U L}$ & -5.743777 & -2.754993 & 1.970978 & -1.603693 & 0.0000 & $1(0)$ \\
\hline T\&R & -4.462872 & -2.771926 & -1.974028 & -1.602922 & 0.0003 & $1(0)$ \\
\hline FW & -4.882401 & -2.74 .613 & -1.968430 & -1.604392 & 0.0001 & $1(0)$ \\
\hline
\end{tabular}

Source: Extracted from E-view 9.0

Co-integration Test: Model I

\begin{tabular}{|c|c|c|c|c|}
\hline $\begin{array}{c}\text { HYPOTHESIZED } \\
\text { CE }\end{array}$ & EIGEN VALUE & $\begin{array}{c}\text { TRACE } \\
\text { STATISTICS }\end{array}$ & $\mathbf{0 . 0 5}$ & PROB \\
\hline None & 0.931781 & 41.56643 & 29.79707 & 0.0014 \\
\hline At most 1 & 0.526069 & 12.03114 & 15.49471 & 0.1554 \\
\hline At most 2 & 0.293227 & 3.817507 & 3.841466 & 0.0507 \\
\hline At most 3 & 0.526069 & 17.825621 & 9.084562 & 0.0551 \\
\hline At most 4 & 0.503462 & 8.110456 & 4.692845 & 0.0030 \\
\hline At most 5 & 0.216816 & 3.0924193 & 4.234345 & 0.4389 \\
\hline
\end{tabular}

Model II

\begin{tabular}{|c|c|c|c|c|}
\hline None & 0.997617 & 69.88213 & 29.79787 & 0.0000 \\
\hline At most 1 & 0.582214 & 9.489115 & 15.49471 & 0.3221 \\
\hline At most 2 & 0.733001 & 0.761256 & 3.841466 & 0.3829 \\
\hline At most 3 & 0.532146 & 4.181469 & 3.004621 & 0.0038 \\
\hline At most 4 & 0.2178531 & 2.657316 & 2.059346 & 0.0934 \\
\hline At most 5 & 0.1461735 & 1.430456 & 1.800811 & 0.5418 \\
\hline
\end{tabular}

Model III

\begin{tabular}{|c|c|c|c|c|}
\hline None & 0.947510 & 64.68280 & 23.56435 & 0.0002 \\
\hline At most 1 & 0.565876 & 8.876567 & 12.34256 & 0.3112 \\
\hline At most 2 & 0.875646 & 1.987087 & 3.546890 & 0.8765 \\
\hline At most 3 & 0.653241 & 3.768909 & 4.098978 & 0.0075 \\
\hline At most 4 & 0.546321 & 2.613657 & 2.653950 & 0.0768 \\
\hline At most 5 & 0.153678 & 1.769543 & 1.765899 & 0.5418 \\
\hline
\end{tabular}


